\title{
The Expression Patterns of Connexin Isoforms in the Rat Caput Epididymis During Postnatal Development
}

\author{
Su-Yong $\mathrm{Han}^{1}$ and $\mathrm{Ki}-\mathrm{Ho} \mathrm{Lee}^{2 *}$ \\ ${ }^{1}$ College of Liberal Arts and Sciences, Anyang University, Incheon, Korea 417-833, ${ }^{2}$ Department of Biochemistry and \\ Molecular Biology, College of Medicine, Eulji University, Daejeon, Korea 301-746
}

\begin{abstract}
Intercellular interactions are important for the proper development and regulation of tissue function. This is especially necessary in the epididymis, a part of male reproductive tract where sperm become mature and acquire their fertilizing capacity. The caput region of the epididymis consists of several types of cells, including principal, basal, and apical cells. Direct intercellular communication is thus required to precisely regulate the functions of the caput epididymis. In this regard, connexin $(C x)$ is a molecule that forms channels, which allow the direct exchange of small molecules between cells, enabling intercellular communication. In this study, the expression of $C x$ isoforms in the caput epididymis at different postnatal ages was determined by using quantitative real-time polymerase chain reaction analysis. Nine of $13 C x$ isoforms were detected. The transcript levels of $C x 30.3,31,31.1,32$, and 40 were highest at 45 days of age, while the expression of $C x 43$ and 45 gradually decreased with age. A substantial fluctuation of Cx26 expression was detected, with significant decreases before and during puberty, followed by a transient increase at adult-hood and rapid decreases at an old age. A significant increase in Cx37 transcript was observed at 25 days of age, followed by gradual decreases at adult and old ages. These results indicate the significant differential expression of various $C x$ isoforms in the caput epididymis during postnatal development. It further suggests that the functional regulation and developmental maturation of the caput epididymis are highly related to the postnatal age-related differential expression of $C x$ isoforms.
\end{abstract}

(Key words : Connexin, Caput epididymis, Gene expression, Development, Male)

\section{INTRODUCTION}

The epididymis is a part of the male reproductive excurrent ductal system, between the efferent ducts and the vas deferens. The epididymis consists of a single coiled tubular duct and has a polarized epithelial layer surrounded by a smooth muscle layer (Sullivan, 2004). During embryonic development, under the influence of androgens secreted from the male gonad, the Wolffian ducts develop into a number of male reproductive organs, such as the epididymis, vas deferens, and seminal vesicles (Hannema and Hughes, 2007). In general, the differentiation of epididymal epithelial cells appears in two developmental phases during postnatal development a first phase in the early neonatal period, in which halo cells appear from undifferentiated cells, and a second phase, in which there is a sequential differentiation of other cell types until adulthood (Arrotéia et al., 2012). It is believed that a number of lumicrine factors produced by the testis, such as androgens, growth factors, and other secretory molecules, play important roles in the differentiation of the epithelium (Hinton et al., 2011).

Based on anatomical and functional differences, the epididymis is divided into four segments, the initial segment, caput epididymis, corpus epididymis, and cauda epididymis (Lasserre et al., 2001). Each epididymal segment is confined by connective tissue septa to functionally separate the epididymal regions (Cornwall, 2009). The epithelium of the epididymis is composed of several cell types, including principal, basal, apical, narrow, clear, and halo cells (Arrotéia et al., 2012). Each region of the epididymis has a different cellular organization with distinct cell populations, although the principal cell is the most abundant cell type throughout the entire epididymal duct (Arrotéia et al., 2012). For example, the number of principal cells decreases from $80 \%$ of the total epithelial cell population in the initial segment to $65 \%$ in the cauda epididymis (Robaire and Hermo, 1988).

* Corresponding author: Ki-Ho Lee, Ph.D. Department of Biochemistry and Molecular Biology and Medical Sciences Research Institute, Eulji University, Daejeon, S. Korea 301-746. Tel: +82-42-259-1643, Fax: +82-42-259-1649, E-mail: kiholee@eulji. ac.kr 
However, the number of narrow cells in the total epithelial cell population increases along the epididymis from $3 \%$ in the initial segment to $6 \%$ in the corpus epididymis (Arrotéia et al., 2012). In addition, each cell type in the epididymal epithelium has different roles that influence overall epididymal functions. The chief function of the principal cell is the secretion of a bulk of proteins to regulate luminal protein concentrations (Robaire et al., 2000), while the narrow cell is involved in the intracellular transport of specific molecules between the lumen and epithelial cells (Robaire et al., 2006). The clear cell is likely responsible for the removal of luminal proteins, and the apical cell is related to the regulation of luminal $\mathrm{pH}$ (Hermo et al., 2005). It is reasonable to consider that different cellular compositions along the epididymis would lead to the creation of a specific luminal microenvironment in each epididymal region, resulting in the regionalization of epididymal functions.

The main functions of the epididymis include transport, storage, maturation, and concentration of spermatozoa for male fertility. To accomplish these many functions, the epididymis is required to establish a particular microenvironment through the secretion and absorption of specific proteins and ions at different regions. Because there are several cell types in the epididymal epithelium, a precise regulation of intercellular communication is highly essential to control the functions of the epididymis. This communication requires gap junctional complexes formed by connexin ( $C x)$ molecules (Goodenough and Paul, 2009). There are at least $20 C x$ isoforms in rodents, and the gap junctional complexes allow intercellular interactions by controlling the transfer of small molecules among different cell types (Goodenough and Paul, 2009). In the epididymis, the expression of several $C x$ molecules, including $C x 26,30.3$, $31.1,32$, and 43 , during the early postnatal period has been determined (Dufresne et al., 2003). In addition, the expression patterns of these $C x$ molecules within the head part (initial segment, caput epididymis, and corpus epididymis) and tail part of the epididymis have been examined (Dufresne et al., 2003). However, the presence of other $C x$ isoform transcripts in the epididymis has not been revealed. Moreover, the definite regional comparison of $C x$ isoform expression has not been attempted.

In the present study, the existence of $C x$ isoforms transcripts in the caput epididymis was examined by quantitative real-time PCR analysis. In addition, the expression patterns of $C x$ isoforms in the caput epididymis, from the neonatal to old age, during the postnatal period were determined and compared with previous research findings.

\section{MATERIALS AND METHODS}

\section{Experimental animals and tissue isolation}

Male Sprague Dawley rats at different postnatal ages were used for the present study. Neonatal rats at 1 week $(n=10)$ and 15 days $(n=10)$ of ages were obtained from pregnant female rats purchased from Samtako (O San, S. Korea). Live animals at 25 days $(n=8)$ and 45 days $(n=7)$ of age were also obtained from Samtako. Free access to food and drinking water were permitted for experimental animals. Adult animals at 5 months $(\mathrm{n}=5)$ and 1 year $(\mathrm{n}=3)$ of age and elderly animals at 2 years $(n=3)$ of age were kindly provided by the Aging Tissue Bank (Department of Pharmacology, Pusan National University, S. Korea).

$\mathrm{CO}_{2}$ stunning was employed to anesthetize experimental animals at proper ages. The lower abdominal area was then exposed, and the testis and epididymis were dissected out. The epididymis was separated from the testis in cold phosphate buffered saline (PBS). The epididymis was further cut into the initial segment, caput epididymis, corpus epididymis, and cauda epididymis based on information from previous research (Guoet al., 2007; Robaire et al., 2006). The caput epididymis at 1 week, 15 days, or 25 days of age was pooled because each caput epididymal segment was too small to acquire sufficient amounts of total RNA for real-time PCR analysis. The caput epididymis was rapidly frozen in liquid nitrogen and kept at $-80^{\circ} \mathrm{C}$ until the isolation of total RNA.

\section{Extraction of total RNA from the caput epididy- mis and preparation of complementary DNA (CDNA)}

The frozen caput epididymis was homogenized with a polytron homogenizer (Fisher Scientific, Pittsburgh, PA) in an Eppendorf tube with easy-Blue total RNA extraction solution (iNtRON Biotech, Sungnam, S. Korea). Using the phenolchloroform extraction method, a RNA pellet was obtained. The RNA was dissolved in RNA storage buffer (Ambion, Austin, TX) and then stored at $-80^{\circ} \mathrm{C}$ until the generation of first strand cDNA. The concentrations of total RNA were measured by an UV spectrophotometer (Eppendorf, New 
York, NY). The qualities of total RNA were checked by gel electrophoresis.

Onemicrogram of total RNA was used for a reverse transcription (RT) reaction to generate the first stranded cDNA in the ImProm-II ${ }^{\mathrm{TM}}$ reverse transcription system (Promega, Madison, WI). The RT reaction was carried out with oligo-dT primer in a total volume of $20 \mu \mathrm{L}$. The RT reaction was performed at $25^{\circ} \mathrm{C}$ for $5 \mathrm{~min}, 42^{\circ} \mathrm{C}$ for $1 \mathrm{hr}$, and $70^{\circ} \mathrm{C}$ for $15 \mathrm{~min}$. The generated cDNAs were stored in $-20^{\circ} \mathrm{C}$ until real-time PCR analysis.

\section{Quantitative real-time polymerase chain reaction (PCR) analysis}

Table 1 shows the oligonucleotide primers used for real-time PCR analysis. In preliminary examinations, the expression of $13 C x$ isoforms $(C x 26,30,30.3,31,31.1,32$, $33,36,37,40,43,45$, and 50) in the caput epididymis was tested. However, only nine transcripts $(C x 26,30.3,31,31.1$, $32,37,40,43$, and 45) of $13 C x$ isoforms were detected, and the expression patterns of these $C x$ isoforms were determined in the present study.

To conduct real-time PCR analysis, a mixture of $1 \mu \mathrm{L}$ of cDNA, 10 pmol of primer set, and $10 \mu \mathrm{L}$ of master mix (Finnzymes, Espoo, Finland) was prepared, and nuclease free-water was added to a final volume of $20 \mu \mathrm{L}$. A pre-denaturation step of the PCR mixture was carried out at $95^{\circ} \mathrm{C}$ for $5 \mathrm{~min}$ to form single-strands from the cDNA template. The PCR procedure was then followed by a number of cycles of denaturation at $95^{\circ} \mathrm{C}$ for $30 \mathrm{sec}$, annealing at $\mathrm{T}_{\mathrm{m}}$ for $30 \mathrm{sec}$, and extension at $72^{\circ} \mathrm{C}$ for 30 sec. An extra extension step at $72^{\circ} \mathrm{C}$ for $10 \mathrm{~min}$ was added at the end of the PCR. Cyclophilin A (Ppia) was used as an internal quantitative control for PCR. All PCR products were examined through agarose gel electrophoresis to check the size of the PCR products.

\section{Data collection and statistical analysis}

Independent and quadruplicate RT-PCR reactions were conducted to obtain a mean and standard error for each age group. The expression levels of $C x$ molecules were normalized to the expression of Ppia. Real-time PCR results were expressed in relative expression ratios between $C x$ and Ppia. Statistical significance of expression levels for each $C x$ isoform among different postnatal age groups was determined by one-way ANOVA, followed by Duncan's test, a post-hoc analysis. When the $\mathrm{P}$ value was lower than 0.05 , results were regarded as statistically significant.

Table 1. List of oligonucleotide primers utilized for real-time PCR analysis

\begin{tabular}{|c|c|c|c|}
\hline $\begin{array}{c}\text { Gene } \\
\text { (GenBank ID) }\end{array}$ & $\begin{array}{l}\text { Primer sequence } \\
\quad\left(5^{\prime} \rightarrow 3^{\prime}\right)\end{array}$ & $\begin{array}{c}\mathrm{Tm} \\
\left({ }^{\circ} \mathrm{C}\right)\end{array}$ & $\begin{array}{l}\text { PCR product } \\
\text { size (bps) }\end{array}$ \\
\hline $\begin{array}{c}C x 26 \\
(\mathrm{NM} 001004099)\end{array}$ & $\begin{array}{l}\text { (F) TCCTCTTCATCTTCCGCATC } \\
\text { (R) CCGTTTCTTTTCGTGTCTCC }\end{array}$ & 55 & 233 \\
\hline $\begin{array}{c}C x 30.3 \\
(\mathrm{NM} 053984)\end{array}$ & $\begin{array}{l}\text { (F) CCCAATGTCTGCTATGACGA } \\
\text { (R) CACAGCAGCCTTGAAGATGA }\end{array}$ & 57 & 243 \\
\hline $\begin{array}{c}C \times 31 \\
(\mathrm{NM}+019240)\end{array}$ & $\begin{array}{l}\text { (F) TTGAGCGGTGTGAACCAGTA } \\
\text { (R) TGTTGGAGATGGGGAAGAAG }\end{array}$ & 57 & 193 \\
\hline $\begin{array}{c}\text { Cx31.1 } \\
(\mathrm{NM}-019241)\end{array}$ & $\begin{array}{l}\text { (F) CATCGTCTGCATCCTGCTTA } \\
\text { (R) ATGAGGTCGCTTGAGAGGAA }\end{array}$ & 55 & 165 \\
\hline $\begin{array}{c}\text { Cx32 } \\
\text { (NM_017251) }\end{array}$ & $\begin{array}{l}\text { (F) AGAATCATGGTGCTGGTGGT } \\
\text { (R) CCTCAAGCCGTAGCATTTTC }\end{array}$ & 57 & 235 \\
\hline $\begin{array}{c}C \times 37 \\
(\mathrm{NM} 021654)\end{array}$ & $\begin{array}{l}\text { (F) AGTGTCTGTACCTTGGATGCC } \\
\text { (R) CAGCACACTTAGCCAAGAGC }\end{array}$ & 51 & 223 \\
\hline $\begin{array}{c}C x 40 \\
\text { (NM } 019280)\end{array}$ & $\begin{array}{l}\text { (F) ATACCATTCAGCCTGGTTGC } \\
\text { (R) CGGCCTCTTTAGCTTTCTCA }\end{array}$ & 57 & 189 \\
\hline $\begin{array}{c}\bar{C} \times 43 \\
(\mathrm{NM} 012567)\end{array}$ & $\begin{array}{l}\text { (F) AGCAAGCTAGCGAGCAAAAC } \\
\text { (R) GAGTTCATGTCCAGCAGCAA }\end{array}$ & 55 & 151 \\
\hline $\begin{array}{c}C x 45 \\
(\mathrm{NM}-001085381)\end{array}$ & $\begin{array}{l}\text { (F) GATCATCCTGGTTGCTACTC } \\
\text { (R) GATCCTCTTCATGGTCCTCT }\end{array}$ & 51 & 173 \\
\hline Ppia & $\begin{array}{l}\text { (F) GGCAAATGCTGGACCAAACAC } \\
\text { (R)TTAGAGTTGTCCACAGTCGGAGATG }\end{array}$ & 59 & 196 \\
\hline
\end{tabular}

$C x$ : connexin; Ppia : peptidylprolyl isomerase A (cyclophilin A). 
RESULTS

1. Expression patterns of $C \times 26, C \times 30.3$, and $C \times 31$ in the rat caput epididymis during the postnatal period

The expression pattern of $C x 26$ is shown in Fig. 1a. Expression levels of $C x 26$ were higher at 1 week of age

(a)

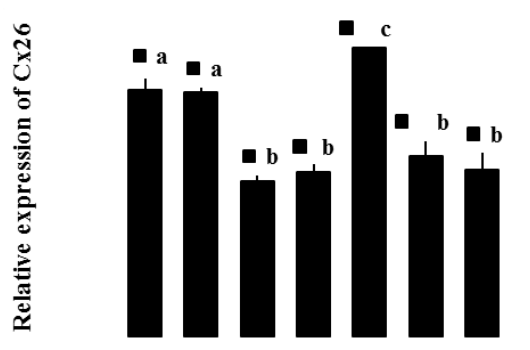

Experimental group (b)

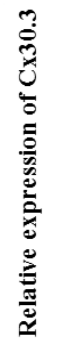

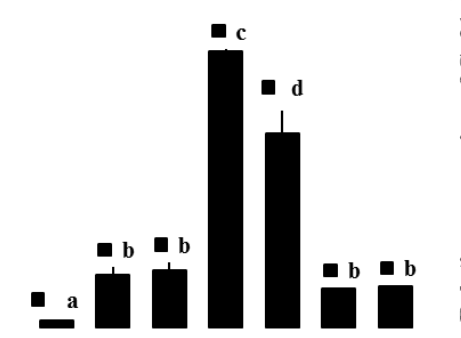

Experimental group (neonatal period) and 15 days of age than at 25 days of age and 45 days of age. However, a transient increase of Cx26 transcript level was observed in the caput epididymis at 5 months of age, followed by a significant drop of level at 1 year of age (Fig. 1a). There was no expression change between 1 year of age and 2 years of age (Fig. 1a).

Fig. 1. Expression patterns of $C \times 26, C \times 30.3$, and $C \times 31$ in the rat caput epididymis during the postnatal period. The relative expression levels of $C \times 26$ (A), Cx30.3 (B), and Cx31 (C) are shown. Statistically significant differences $(p<0.05)$ are indicated in different letters. $D$ : day, M: month, $W$ : week, and $Y$ : year.

(a)

ت. (b)

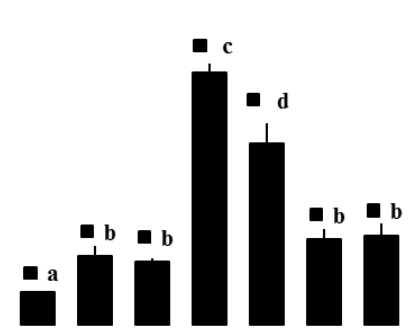

Experimental group

Uี

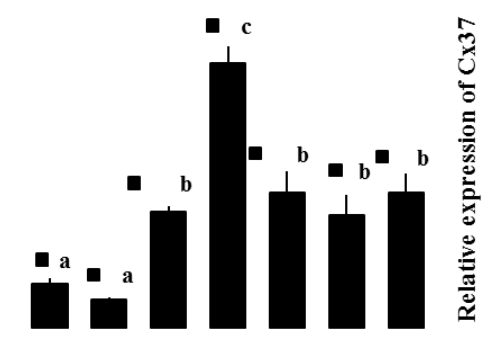

Experimental group (c)

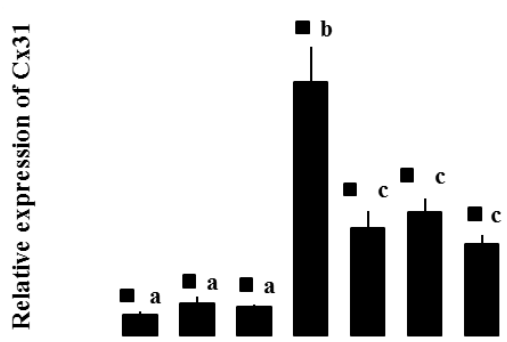

(c)

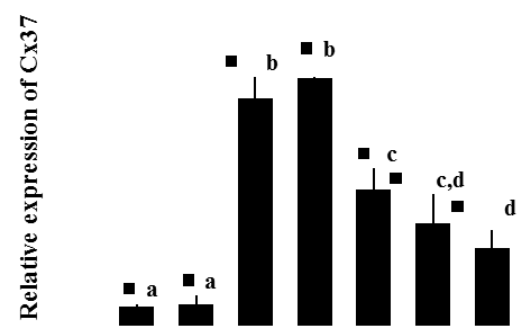

Experimental group

Fig. 2. Expression patterns of $C \times 31.1, C \times 32$, and $C \times 37$ in the rat caput epididymis during the postnatal period. The relativeexpression levels of $C \times 31.1(A), C x 32(B)$, and $C \times 37(C)$ are shown. Statistically significant differences $(p<0.05)$ are indicated in different letters. $D$ : day, M: month, W: week, and Y: year.

(a)

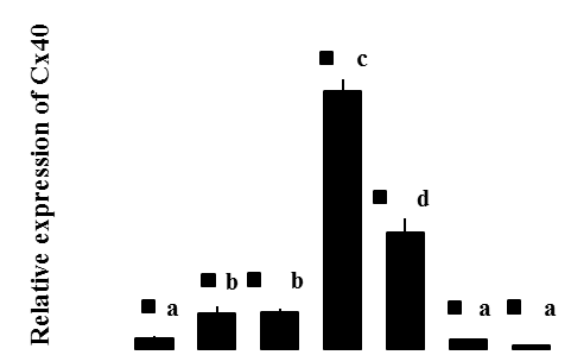

Experimental group (b)

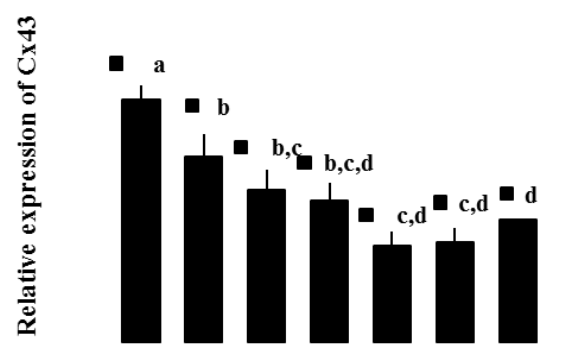

Experimental group (c)

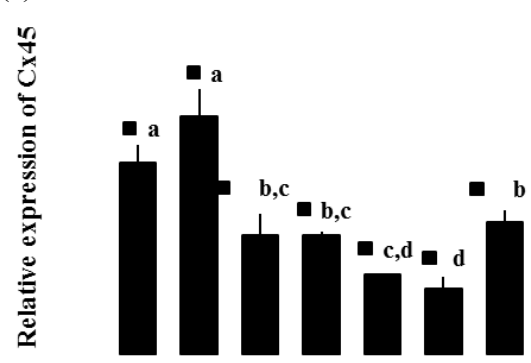

Experimental group

Fig. 3. Expression patterns of $C x 40, C x 43$, and $C x 45$ in the rat caput epididymis during the postnatal period. The relative expression levels of $C x 40$ (A), Cx43 (B), and Cx45 (C) are shown. Statistically significant differences $(p<0.05)$ are indicated in different letters. D: day, M: month, W: week, and Y: year. 
epididymis was found at 1 week of age (Fig. 1b). However, the gene expression of $C x 30.3$ significantly increased at 15 days of age, compared with 1 week of age (Fig. 1b). There was no difference in Cx30.3 transcript levels between 15 days of age and 25 days of age, while the $C \times 30.3$ transcript level drastically increased at 45 days of age (Fig. 1b). The expression of $C x 30.3$ in the caput epididymis significantly decreased at 5 months of age, compared to 45 days of age (Fig. 1b). The subsequent decrease in Cx30.3 gene expression was detected at 1 year of age, and the expression levels of $C x 30.3$ between 1 year of age and 2 years of agewere not statistically different (Fig. 1b).

Cx31 gene expression did not change during the early postnatal period, but a significant increase in $C \times 31$ expression was observed at 45 days of age (Fig. 1c). A dramatic decrease in $C x 31$ expression was then followed at 5 months of age, with no significant change in Cx31 mRNA levels at adult and old ages (Fig. 1c).

\section{Expression patterns of $C \times 31.1, C \times 32$, and $C \times 37$ in the rat caput epididymis during the postnatal period}

The expression pattern of $C x 31.1$ was had similarities to the expression pattern of $C \times 30.3$. The first significant increase of $C \times 31.1$ gene expression was detected at 15 days of age (Fig. 2a). An additional rise in Cx31.1 transcript level was observed at 45 days of age, followed by a significant decrease at 5 months of age (Fig. 2a). At older ages (1 year and 2 years), the abundance of $C \times 31.1$ mRNA was significantly lower than at 5 months of age (Fig. 2a).

There was no significant difference in $C x 32$ transcript levels between 1 week of age and 15 days of age (Fig. 2b). However, the abundance of $C \times 32$ mRNA greatly increased at 25 days of age, and the highest level of Cx32 transcripts was detectedat 45 days of age (Fig. 2b). After a transient decrease of $C x 32$ mRNA level at 5 months of age, there was no significant change of $C x 32$ abundance in the caput epididymis during the elderly period (Fig. 2b).

Minimal expression of the $C \times 37$ in the caput epididymis was found at early postnatal ages, 1 week of age and 15 days of age (Fig. 2c) however, a surge in Cx37 expression was detected at 25 days of age (Fig. 2c). The abundance of Cx37 mRNA did not significantly change at 45 days of age, compared with 25 days of age (Fig. 2c). The level of Cx37 transcripts significantly dropped at 5 months of age, followed by gradual decreases of $C x 37$ mRNA levels at 1 year of age and 2 years of age (Fig. 2c).

\section{Expression patterns of $C x 40, C x 43$, and $C x 45$ in the rat caput epididymis during the postnatal period}

Expression of the $C x 40$ gene significantly increased at 15 days of age, compared with 1 week of age (Fig. 3a). A tremendous increase of $C x 40$ gene expression was detected at 45 days of age, followed by a transient decrease at 5 months of age (Fig. 3a). Cx40 gene expression at 1 year of age and 2 years of age was minimal (Fig. 3a).

Expression patterns of $C x 43$ in the caput epididymis during postnatal development are shown in Fig. 3b. $C x 43$ gene expression was highest at 1 week of age, followed by a gradual decrease with age (Fig. 3b). After puberty, there was no significant change of $C x 43$ mRNA level in the caput epididymis (Fig. 3b). The abundance of $C x 45$ transcripts was significantly higher at 1 week of age and 15 days of age, compared with other ages (Fig. 3c). There was a steady decrease of $C x 45$ gene expression until 1 year of age, followed by an increase at 2 years of age (Fig. 3c).

\section{DISCUSSION}

Direct intercellular communication through $C x$ is important for the regulation and maintenance of specific tissue functions. The current research demonstrates the presence of a number of $C x$ isoforms in the caput epididymis of the rat. In addition, the differential expression of $C x$ isoforms during the postnatal period has been revealed by real-time PCR analysis.

The existence of various $C x$ isoforms in the epididymis has been previously observed (Cyr et al., 1996; Dufresne et al., 2003). However, no research has been conducted to determine the expression patterns of $C x$ isoforms in defined epididymal regions at multiple developmental stages. The present study examined the expression of $C x$ isoforms in the rat caput epididymis during the postnatal period. Dufresne et al. (2003) have shown the expression of $C x 26,30.3,31.1$, and 32 in the caput epididymis and the expression of $C \times 43$ in the adult caput epididymis (Cry et al., 1996). In our research, in addition to finding these $C x$ isoforms, the expression of $C x 31,37,40$, and 45 in the caput epididymis was detected. These findings indicate possibility of the existence of other $C x$ isoforms, except $13 C x$ isoforms tested 
in the present study. Indeed, the expression of particular $C x$ isoform in various tissues is frequently observed (Bosco et al., 2011). Thus, the existence of other $C x$ isoforms should be investigated in future studies.

The localization of $C x$ isoforms in the epididymis has been studied (Cyr et al., 1996; Dufresne et al., 2003). Cx43 is between the principal and basal cells in the caput epididymis and does not exist between adjacent principal cells (Cyr et al., 1996). In the cauda epididymis, Cx43 also exists between clear and basal cells and between myoid cells surrounding the epididymal duct(Cry et al., 1996). The immuno-localization of $\mathrm{Cx} 32$ in the epididymis is detected between adjacent principal cells and between principal and basal cells (Dufresne et al., 2003). In addition, the localization of $C \times 26$ at the apical region of the epididymal epithelial cells is found in the early postnatal animal (Dufresne et al., 2003). Moreover, the co-localization of Cx26 and 32 between principal cells is detected in the epididymis (Dufresne et al., 2003). The expression of multiple $C x$ isoforms, as shown in the present study, implies the possibilities of the localization of more $C x$ isoforms in a specific caput epithelial cell than previous observations.

Differentiation of the epididymal epithelium into different cell types does not occur until 14 days after birth (Sun and Flickinger, 1979). After full differentiation of the epididymis until 45 days of age, the expansion of differentiated epididymal cells takes place between 45 days and 3 months of ages (Sun and Flickinger, 1979). Overall findings suggest the differential expression of $C x$ isoforms during the postnatal period. Indeed, our present study shows the expression change of several $C x$ isoforms in the caput epididymis at different postnatal ages. Dufresne et al. (2003) have also demonstrated similar findings in the rat epididymis. Interestingly, significant increases in the transcripts of CX30.3, 31, 31.1, 32, and 40 in the caput epididymis were detected in our research at 45 days of age. Becausethe end of differentiation and the beginning of epididymal cell expansion occur at 45 days of age, we speculate that this expression increase is related to the maturation of epididymal cells during the postnatal period. A detailed examination on the development of epididymal cells near the early pubertal period requires future investigation.

The hormonal regulation of $C x 43$ gene expression in the epididymis has been examined in previous research. Chemically-induced hypothyroidism at a neonatal age results in the decrease of $C x 43$ mRNA in the proximal epididymis (St-Pierre et al., 2003). Treatment with flutamide, an anti-androgen, leads to a decreased $C x 43$ expression in the cauda epididymis of adult boar, indicating possible androgendependent regulation of $C x 43$ expression in the epididymis (Lydka et al., 2011). In the stallion, the cryptorchid results in a significant decrease of $C x 43$ expression (Hejmej et al., 2007). Recently, Dubé et al. (2012) have reported the regulation of $C x 43$ expression by epidermal growth factor in the human epididymis. These observations imply that the expression of $C x$ genes in the epididymis is precisely regulated by various factors, including testicular factor(s). The serum testosterone concentration of the male rat is significantly increased between 40 and 50 days of age (Brown-Grant et al., 1975). Thus, it is possible that increases in $C x 30.3,31,31.1,32$, and 40 gene expression in the caput epididymis at 45 days of age is influenced by testicular testosterone and/or growth factors.

It is notable that a significant induction of $C \times 37$ mRNA level is observed at 25 days of age, indicating that $C \times 37$ expression is regulated by molecular mechanism(s) distinct from other $C x$ isoforms. In addition, transcript levels of $C x 43$ and 45 , at 45 days of age, are greatly lower than transcript levels at the early neonatal period. These observations indicate that $C x 43$ and 45 may play an important role in the differentiation and maturation of the caput epididymis during the early postnatal phase. At this point, it is uncertain what causes high levels of $C \times 43$ and 45 gene expressions in the caput epididymis of the neonatal rat molecular factor(s) involved in the early postnatal development of the epididymis potentially influence $C \times 43$ and 45 gene expression. Together, these results suggest that the transcriptional regulation of $C x$ isoforms in the caput epididymis is highly complicated and requires the coordinated actions of various factors at each period of postnatal development.

In conclusion, the functional maturation and development of the rat caput epididymis is associated with the expression of a number of $C x$ isoforms at distinct postnatal stages. Aging could influence the gene expression of $C x$ isoforms in the caput epididymis and may also lead to functional alterations inthe caput epididymis of the aged male. The castration and/or efferent ductual ligation would provide valuable information of the effect of androgen on the expression of $C x$ isoform in the caput epididymis. 
Han and Lee ; Connexin Isoforms in Rat Caput Epididymis

\section{ACKNOWLEDGEMENTS}

This research was partly supported by the Basic Science Research Program through the National Research Foundation of Korea (NRF) funded by the Ministry of Education, Science and Technology (20110003864 and 20120007661).

\section{REFERENCES}

Arrotéia, K. F., Garcia, P. V., Barbieri, M. F., Justino, M. L. and Pereira, L. A. V. 2012. The epididymis: embryology, structure, function and its role in fertilization and infertility. In: Embryology-Updates and Highlights on Classic Topics. (Ed: L. A. V. Pereira) In Tech. Croatia pp.41-66.

Bosco, D., Haefliger, J. A. and Meda, P. 2011. Connexins: key mediators of endocrine function. Physiol. Rev. 91:1393-1445.

Brown-Grant, K., Fink, G., Greig, F. and Murray, M. A. 1975. Altered sexual development in male rats after oestrogen administration during the neonatal period. J. Reprod. Fertil. 44:25-42.

Cornwall, G. A. 2009. New insights into epididymal biology and function. Hum. Reprod. Update. 15:213-227.

Cyr, D. G., Hermoand, L. and Laird, D. W. 1996. Immunocytochemical localization and regulation of connexin 43 in the adult rat epididymis. Endocrinology. 137:1474-1484.

Dubé, E., Dufresne, J., Chan, P. T. and Cyr, D. G. 2012. Epidermal growth factor regulates connexin 43 in the human epididymis: role of gap junctions in azoospermia. Hum. Reprod. 27:2285-2296.

Dufresne, J., Finnson, K. W., Gregory, M. and Cry, D. G. 2003. Expression of multiple connexins in the rat epididymis indicates a complex regulation of gap junctional communication. Am. J. Physiol. Cell. Physiol. 284:33-43.

Goodenough, D. A. and Paul, D. L. 2009. Gap junctions. Cold Spring Harb. Perspect. Biol. 1:a003061.

Guo, W., Qu, F., Xia, L., Guo, Q., Ying, X. and Ding, Z. 2007. Identification and characterization of ERp29 in rat spermatozoa during epididymal transit. Reproduction. 133:575-584.

Hannema, S. E. and Hughes, I. A. 2007. Regulation of Wolffian duct development. Hormone Res. 67:142-151.

Hejmej, A., Kotula-Balak, M., Sadowska, J. and Bilińska, B. 2007.
Expression of connexin 43 protein in testes, epididymides and prostates of stallions. Equine Vet. J. 39:122-127.

Hermo, L., Chong, D. L., Moffatt, P., Sly, W. S., Waheed, A. and Smith, C. E. 2005. Region- and cell-specific differences in the distribution of carbonic anhydrases II, III, XII, and XIV in the adult rat epididymis. J. Histochem. Cytochem. 53:699-713.

Hinton, B. T., Galdamez, M. M., Sutherland, A., Bomgardner, D., $\mathrm{Xu}$, B., Abdel-Fattah, R. and Yang, L. 2011. How do you get six meters of epididymis inside a human scrotum? J. Androl. 32:558-564.

Lasserre, A., Barrozo, S., Tezón, J. G., Miranda, P. V. and Vazquez-Levin, M. H. 2001. Human epididymal proteins and sperm function during fertilization: an update. Biol. Res. 34:165-178.

Lydka, M., Kopera-Sobota, I., Kotula-Balak, M., Chojnacka, K., Zak, D. and Bilinska, B. 2011. Morphological and functional alterations in adult boar epididymis: effects of prenatal and postnatal administration of flutamide. Acta Vet. Scand. 53:12. doi: $10.1186 / 1751-0147-53-12$.

Robaire, B. and Hermo, L. 1988. Efferent ducts, epididymis and vas deferens: structure, functions and their regulation. In: The Physiology of Reproduction. (Eds: E. Knobil and J. Neil) Raven Press. New York pp. 999-1080.

Robaire, B., Syntin, P. and Jervis, K. 2000. The coming of age of the epididymis. In: Testis, Epididymis and Technologies in the Year 2000. (Eds: B. Jégou, C. Pineau and J. Saez) Springer: Hildenberg. New York pp. 229-262.

Robaire, B., Hinton, B. T. and Orgebin-Crist, M. C. 2006. The epididymis. In: Knobil and Neill's Physiology of Reproduction. (Eds: J. D. Neill) Elsevier. New York pp. 1071-1148.

St-Pierre, N., Dufresne, J., Rooney, A. A. and Cyr, D. G. 2003. Neonatal hypothyroidism alters the localization of gap junctional protein connexin 43 in the testis and messenger RNA levels in the epididymis of the rat. Biol. Reprod. 68:1232-1240.

Sullivan, R. 2004. Male fertility markers, myth or reality. Ani. Reprod. Sci. 82-83:341-347.

Sun, E. L. and Flickinger, C. J. 1979. Development of cell types and of regional differentiation in the postnatal rat epididymis. Am. J. Anat. 154:27-55.

(Received Jul. 6, 2013; Revised Aug. 19, 2013; Accepted Aug. 21, 2013) 